\title{
Allelopathic EfFect of Santa Maria (Parthenium hysterophrous) MULCH ON GROWTH AND YIELD OF SOYBEAN (Glycine max) ${ }^{1}$
}

\author{
Efeito Alelopático da Cobertura Vegetal de Losna-Branca (Parthenium hysterophorus) no \\ Crescimento e na Produtividade da Soja (Glycine max)
}

\author{
SHEHZAD, M. ${ }^{2}$, HUSSAIN, S. ${ }^{2}$, MUBEEN, K. ${ }^{3}$, SHOAIB, M. ${ }^{4}$, SARWAR, N. ${ }^{5}$, JAVEED, H.M.R. ${ }^{6}$, \\ AHMAD, A. ${ }^{2}$, and KHALID, S. ${ }^{2}$
}

\begin{abstract}
To determine the effect of Santa Maria (Parthenium hysterophrous) mulch on growth and yield of soybean, a study was conducted at the Department of Agronomy, Faculty of Agriculture, The University of Poonch, Rawalakot, Azad Jammu and Kashmir. The experiment was conducted in the laboratory as well as in the greenhouse. Parthenium surface mulch and soil incorporation was practiced at different levels in laboratory as well as in greenhouse. Higher allelopathic potential was found by the treatments of Parthenium soil incorporation, especially when soil incorporation of Parthenium herbage @ 5 ton ha h $^{-1}$ was practiced. This could be because of the presence of soil moisture that enhanced the decomposition of Parthenium therefore, retarded the growth and other parameters. The study showed that Parthenium hysterophrous considerably reduced the emergence, seedling growth and yield of soybean.
\end{abstract}

Keywords: Parthenium hysterophrous, surface mulching, soil incorporation, glycine max.

\begin{abstract}
RESUMO - Para determinar o efeito da cobertura vegetal de losna-branca (Parthenium hysterophorus) sobre o crescimento e a produtividade da soja, foi realizado um estudo no Departamento de Agronomia da Faculdade de Agricultura da Universidade de Poonch, Rawalakot, Azad Jammu e Kashmir. O experimento foi conduzido tanto em laboratório quanto em estufa. A cobertura vegetal de Parthenium na superficie do solo e a incorporação ao solo ocorreram em diferentes niveis em laboratório e também na estufa. Obteve-se o maior potencial alelopático através dos tratamentos de incorporação de Parthenium ao solo, especialmente com a incorporação de $5 \mathrm{t} \mathrm{ha^{-1 }}$ de forragem de Parthenium ao solo. Esse fato pode ser devido à presença da umidade no solo, que aumentou a decomposição de Parthenium, levando ao retardo do crescimento e de outros parâmetros. O estudo mostrou que a espécie Parthenium hysterophorus causou redução significativa da emergência, do crescimento das mudas e da produtividade da soja.
\end{abstract}

Palavras-chave: Parthenium hysterophrous, cobertura vegetal na superfície do solo, incorporação ao solo, Glycine max.

\section{INTRODUCTION}

Soybean (Glycine max) is a leguminous crop, and a worldwide important oilseed crop that has variation, including an extensive range of climatic, soil and development circumstances. However, it is frequently developed on rain-fed territories (Fageria et al., 1997). Soybean was introduced in Azad Jammu and Kashmir in 2002 and gave very encouraging results in terms of growth, yield and nodulation (Tahir et al., 2009; Abbasi et al., 2010). Soybean is a rare crop because of its significant traits: it has almost 37 to $42 \%$

Recebido para publicação em 1.11.2015 e aprovado em 23.3.2016.

2 Department of Agronomy, The University of Poonch Rawalakot (AJK), Pakistan; ${ }^{3}$ Muhammad Nawaz Shareef, University of Agriculture Multan, Pakistan; ${ }^{4}$ Agronomic Research Institute, AARI, Faisalabad, Pakistan; ${ }^{5}$ Department of Agronomy, Bahauddin Zakariya University Multan, Pakistan; ${ }^{6}$ Department of Environmental Sciences, COMSATS Institute of Information Technology, Vehari, Pakistan, <m.shahzaduaf@gmail.com>. 
high-quality protein, 29\% carbohydrate and 17 to $24 \%$ oil contents, $85 \%$ of which are polyunsaturated fatty acid with lenoleic and linolenic acids, which are not produced by the human body (Balasubramaniyan and Palaniappan, 2003). It is one of the major significant and widely developed crops that contribute $30 \%$ of the world's vegetable oil production. Moreover, it has also been used as a supply for bio-diesel fuels (Graham and Vance, 2003). World total production of soybean is 268.2 million metric tonnes, cultivated over an area of 108.69 million ha. The average worldwide yield of soybean crop is 2.47 metric tonnes ha-1 (USDA, 2013).

Allelopathy is a combination of two Greek words: allelo means "mutual harm" and pathy means "suffering" (Willis, 2007). According to Stamp (2003), allelopathy is a natural inclination through which a plant develops additional biochemical properties, which can effect development, endurance and imitation of all plants. These constituents are known as allelo-chemicals and can have an advantageous or disadvantageous consequence on the studied individuals. Allelopathy could be a safe phenomenon if it is used confidently in weed management so as to increase crop yield (Putnam et al., 1983). Developed countries have shown great attention to this type of weed management. Through knowledge of the relationship between selectivity and toxicity, various plant parts are used as inhibitors (Picman and Picman, 1984).

Santa Maria (Parthenium hysterophrous) belongs to the family Asteraceae and is one of the highly damaging weeds in the world. It is found in almost every part of Pakistan. It is a toxic and destructive wild plant and accounts to have pharmacological characteristics beside various infections such as rheumatism, hepatic amoebiasis and abnormal new mass of tissue (Sarita et al., 2011). On other hand, Parthenium has been identified to have a negative influence on crop development, biodiversity, mammal husbandry, human fitness and even high ecological reliability. It has some water dissolving allelo-chemicals such as phenolic acids and parthenin, a sesquiterpene lactone with pseudoguaianolide character in different parts of the wild plant (Singh et al., 2003). Parthenium has been rapidly spreading in Pakistan for the last 20-30 years and is now a serious weed of wastelands and grazing lands, especially in rainfed areas (Javaid and Anjum, 2006). Some researchers have reported the allelopathic nature of Parthenium (Singh et al., 2003). They found that allelopathic natural action in crops has constructive and destructive effects on yielding systems. The function of the allelopathic possessions of many crops has been recommended for wild plant supervision because of the likelihood of decreasing the use of costly, pollutant artificial herbicides (Kruse et al., 2000; Belz, 2007). Mulches can organize wild plant development by suffocating them or through allelopathic possessions (Erenstien, 2002). Crop residues on the soil surface reduce light interception and prevent weed development by reducing photosynthesis (Kamara et al., 2000). Surface mulching of plant residues improve water holding capacity, heat energy, soil fertility; moreover, they minimize soil and water loss and result in weed suppression (Bu et al., 2002). This calls for further scientific investigation on the allelopathic capacity of this weed for development of soybean. The present study was conducted to observe the allelopathic possessions of Santa Maria (Parthenium hysterophrous) on the development, plant growth and yield of soybean (Glycine max)

\section{MATERIALS AND METHODS}

Two experiments, in a greenhouse and in a laboratory, were performed at the University of Poonch Rawalakot AJK. The experiments were laid out in a Completely Randomized Design (CRD) with three replications and seven treatments. Soybean (Glycine max) variety NARC-02 was used in both laboratory and greenhouse experiments to investigate the allelopathic effects of Santa Maria (Parthenium hysterophrous) on emergence, seedling growth and yield of soybean.

\section{Parthenium herbage}

Fresh plants of Santa Maria (Parthenium hysterophrous) at their vegetative stage were collected from fallow lands of Rawalakot. Plants were dried in shade for one week. The flowers 
from the plants were separated. Then, the leaves, shoot and roots of the plants were cut into small pieces. The pieces of plant parts were mixed to make parthenium herbage. The parthenium herbage was applied as surface mulch and as soil incorporated at different levels at 1 ton ha- ${ }^{-1}, 2.5$ ton ha ${ }^{-1}$ and 5 ton $\mathrm{ha}^{-1}$

\section{Soil sampling and collection}

The soil used in the experiment was collected from a fallow field of the Faculty of Agriculture, Rawalakot AJ\&K. Soil was taken from five different locations of the fallow field from a uniform area of the field at $0-15 \mathrm{~cm}$ depth. After proper mixing, a subsample of about one $\mathrm{kg}$ was taken, air dried and sieved through a $2 \mathrm{~mm}$ sieve for the determination of physical and chemical properties.

The pots were filled with $0.25 \mathrm{~kg}$ soil and five seeds of soybean were sown in each pot with a depth of $2 \mathrm{~cm}$. There were seven treatments with three replications. The laboratory experiment was conducted to observe whether or not Parthenium has adverse effect on emergence of soybean. After the laboratory experiment, the same treatments were repeated in the greenhouse experiment and the treatments were as follows:

$\mathrm{T}_{0}=$ Control

$\mathrm{T}_{1}=$ Surface mulching of Parthenium herbage (a) $0.125 \mathrm{~g}$ per $0.25 \mathrm{~kg}$ or 1 ton $\mathrm{ha}^{-1}$

$\mathrm{T}_{2}=$ Surface mulching of Parthenium herbage (@) $0.312 \mathrm{~g}$ per $0.25 \mathrm{~kg}$ or 2.5 ton ha-1

$\mathrm{T}_{3}=$ Surface mulching of Parthenium herbage (a) $0.625 \mathrm{~g}$ per $0.25 \mathrm{~kg}$ or 5 ton $\mathrm{ha}^{-1}$

$\mathrm{T}_{4}=$ Soil incorporation of Parthenium herbage (a) $0.125 \mathrm{~g}$ per $0.25 \mathrm{~kg}$ or 1 ton $\mathrm{ha}^{-1}$

$\mathrm{T}_{5}=$ Soil incorporation of Parthenium herbage (a) $0.312 \mathrm{~g}$ per $0.25 \mathrm{~kg}$ or 2.5 ton $\mathrm{ha}^{-1}$

$\mathrm{T}_{6}=$ Soil incorporation of Parthenium herbage (a) $0.625 \mathrm{~g}$ per $0.25 \mathrm{~kg}$ or 5 ton ha ${ }^{-1}$

The experiment was visited daily. The time when the first seed started emergence was recorded, and so was the time to start emergence (TSE). Mean emergence time (MET) was calculated according to the equation of Ellis and Robert (1981):

$$
\mathrm{MET}=\Sigma \mathrm{Dn} / \Sigma \mathrm{n}
$$

where $\mathrm{n}$ is the number of seeds that germinated on day $\mathrm{D}$, and $\mathrm{D}$ is the number of days counted from the start of germination.

Seedling density was recorded as emergence count (EC) at complete emergence in each pot. Seed emergence rate was calculated with the following formula:

$$
\frac{\text { Number of emerged seeds }}{\text { Number ofemergence days }}=E R
$$

Final emergence percentage (FEP) was calculated as the ratio between the number of emerged seeds and the total number of planted seeds. Vigor index (VI) was calculated with following formula.

$$
V I=\text { seedling length }(\mathrm{cm}) x \text { emergence }(\%)
$$

With the aid of a meter rod, seedling length (SL) was recorded after three weeks of sowing from the root of the plant to the tip of the uppermost leaf.

With the aid of meter rod, plant height was recorded in centimeters from the base of the plant to the tip at physiological maturity. Root length was measured for each plant with the aid of a ruler. Leaf area of all leaves of five plants was measured for each treatment with the aid of digital leaf area meter, and the average was calculated. The plants were dug up with the aid of spade and washed under flowing water. Five nodules were collected and counted from the individual plants and averaged for number of nodules per plant. The number of pods from the plant were counted at full pod stage and then averaged. The total number of seeds from the plants was counted. Then, the average number of seeds per pod was calculated, and 100-seed weight was recorded from the grain lot by using an electronic balance. This was repeated three times, and then average weight per 100 seeds was recorded.

\section{Statistical analysis}

Analysis of variance (ANOVA) and least significant difference (LSD) tests among means were computed for each character separately, using the software Statistix 8.1. 
Comparison of means for the individual treatments was performed at the $5 \%$ probability level based on the F test of the analysis of variance (Steel et al., 1997).

\section{RESULTS AND DISCUSSION}

The data (Table 1) indicates that soil incorporation of Parthenium affected time to start emergence (TSE) and mean emergence time (MET) to a greater extent, as compared with surface mulching. Soil incorporation of Parthenium showed slow emergence of soybean seeds. Among soil incorporation treatments, Parthenium herbage @ 5 ton ha ${ }^{-1}$ resulted in a significant $(\mathrm{P} \leq 0.05)$ delay as depicted by lower TSE and MET of soybean, which was followed by the treatments of Parthenium herbage (a) 2.5 ton ha ${ }^{-1}$. This could be due to a higher quantity of parthenium herbage in $\mathrm{T}_{5}$ and the presence of sufficient soil moisture at depth during incorporation, which enhanced the activity of Parthenium decomposition, therefore releasing more inhibitory allelochemicals. Parthenium hysterophorus extracts significantly inhibited the seed germination of Eragrostis tef (Tefera, 2002) due to release of phytotoxins from Parthenium leaves (Stephen and Sowerby, 1996). These results are in line with Channappagoudar et al. (2005), who studied the allelopathic effect of Cyperus rotundus,
Commelina benghalensis and Parthenium hysterophrous at two concentrations (5 and $10 \% \mathrm{~W} / \mathrm{V})$ on soybean and reported that Commelina and Cyperus had greater inhibitory effect on germination. Similar results were also reported by Khan et al. (2011), who studied the allelopathic potential of $P$. hysterophrous on soybean, mung bean and maize. They reported that with the increasing concentration of the leaf extract of $P$. hysterophrous, the mean emergence values of soybean, mung bean and maize were more decreased. Parthenium delays emergence time; therefore, its application also negatively influenced EC, ER and FEP of soybean plants. By contrast, in control, more plants were recorded with high emergence rate and final emergence percentage. Similarly, vigor index and seedling length were higher in the control treatment as compared with rest of the treatments. This was due to a slow emergence rate and inability to compete for nutrients. Monica and Rao (2006) studied the allelopathic effects of Parthenium hysterophorus aqueous extracts of weed $(10 \% \mathrm{w} / \mathrm{v})$ and showed both inhibitory and stimulatory influence on percent seed emergence and seedling growth in different varieties of soybean. Khan et al. (2012) also investigated the allelopathic effects of Parthenium hysterophrous on the germination and seedling growth of four wheat cultivars. The results showed significant inhibitory

Table 1 - Effect of Parthenium surface and soil incorporation on emergence, vigor and seedling length of soybean

\begin{tabular}{|c|c|c|c|c|c|c|c|c|}
\hline No. & Treatment & $\begin{array}{l}\text { TSE } \\
\text { (days) }\end{array}$ & $\begin{array}{l}\text { MET } \\
\text { (days) }\end{array}$ & $\mathrm{EC}$ & ER & $\begin{array}{l}\text { FEP } \\
(\%)\end{array}$ & VI & $\begin{array}{l}\mathrm{SL} \\
(\mathrm{cm})\end{array}$ \\
\hline $\mathrm{T}_{0}$ & Control & $4.66 \mathrm{f}$ & $5.93 \mathrm{f}$ & $4.66 \mathrm{a}$ & $0.81 \mathrm{a}$ & $93.33 \mathrm{a}$ & $4023.30 \mathrm{a}$ & $43.00 \mathrm{a}$ \\
\hline $\mathrm{T}_{1}$ & $\begin{array}{l}\text { Surface mulching of Parthenium } \\
\text { herbage @ } 1 \text { ton ha }^{-1}\end{array}$ & $6.00 \mathrm{e}$ & $7.68 \mathrm{e}$ & $4.00 \mathrm{ab}$ & $0.54 \mathrm{~b}$ & $80.00 \mathrm{ab}$ & $2340.00 \mathrm{~b}$ & $28.50 \mathrm{~b}$ \\
\hline $\mathrm{T}_{2}$ & $\begin{array}{l}\text { Surface mulching of Parthenium } \\
\text { herbage @ } 2.5 \text { ton ha }^{-1}\end{array}$ & $7.00 \mathrm{de}$ & 8.16 de & $3.66 \mathrm{ab}$ & $0.44 \mathrm{bc}$ & $73.33 \mathrm{ab}$ & $1030.00 \mathrm{c}$ & $14.16 \mathrm{c}$ \\
\hline $\mathrm{T}_{3}$ & $\begin{array}{l}\text { Surface mulching of Parthenium } \\
\text { herbage @ } 5 \text { ton ha }^{-1}\end{array}$ & $8.66 \mathrm{c}$ & $9.66 \mathrm{bc}$ & $2.66 \mathrm{bcd}$ & 0.27 cde & $53.33 \mathrm{bcd}$ & $360.00 \mathrm{~cd}$ & $6.66 \mathrm{~d}$ \\
\hline $\mathrm{T}_{4}$ & $\begin{array}{l}\text { Soil incorporation of Parthenium } \\
\text { herbage @ } 1 \text { ton ha }{ }^{-1}\end{array}$ & $7.33 \mathrm{~d}$ & $8.83 \mathrm{~cd}$ & $3.00 \mathrm{bc}$ & $0.34 \mathrm{bcd}$ & $60.00 \mathrm{bc}$ & $703.33 \mathrm{~cd}$ & $12.00 \mathrm{c}$ \\
\hline $\mathrm{T}_{5}$ & $\begin{array}{l}\text { Soil incorporation of Parthenium } \\
\text { herbage @ } 2.5 \text { ton } \mathrm{ha}^{-1}\end{array}$ & $10.00 \mathrm{~b}$ & $10.61 \mathrm{~b}$ & $2.00 \mathrm{~cd}$ & $0.19 \mathrm{de}$ & $40.00 \mathrm{~cd}$ & $273.33 \mathrm{~cd}$ & $6.50 \mathrm{~d}$ \\
\hline $\mathrm{T}_{6}$ & $\begin{array}{l}\text { Soil incorporation of Parthenium } \\
\text { herbage @ } 5 \text { ton ha }{ }^{-1}\end{array}$ & $13.00 \mathrm{a}$ & $13.33 \mathrm{a}$ & $1.33 \mathrm{~d}$ & $0.10 \mathrm{e}$ & $26.66 \mathrm{~d}$ & $94.67 \mathrm{~d}$ & $3.56 \mathrm{~d}$ \\
\hline \multicolumn{2}{|c|}{$\operatorname{LSD}(\mathrm{P} \leq 0.05)$} & 1.323 & 1.013 & 1.377 & 0.200 & 27.557 & 842.14 & 4.876 \\
\hline
\end{tabular}

$\mathrm{TSE}=$ Time to start emergence; $\mathrm{MET}=$ Mean emergence time; $\mathrm{EC}=$ emergence count; $\mathrm{ER}=$ Emergence rate; FEP = Final emergence percentage; VI = Vigor index; SL = Seedling length. 
effects $(\mathrm{P}<0.05)$ of Parthenium upon the seed germination and seedling growth of the four wheat cultivars tested in comparison with control. Parthenin is one of other inhibitors relevant for residue allelopathy as simulated under laboratory conditions by delaying germination and reducing plant growth (Regina et al., 2007).

Parthenium mulching reduces plant height and root length when soil incorporation of parthenium@5 ton ha-1 (Figure 1A, B) was applied as compared with control. It can be seen that with the increase in the amount of Parthenium herbage, there were more declines in growth of the soybean plants. However, the treatment $T_{2}$ behaved in similar fashion to $T_{4}$ and $\mathrm{T}_{3}$ showed a similar trend to $\mathrm{T}_{5}$. Overall results for plant height and root length showed that soil incorporation of Parthenium herbage had greater influence more as compared with surface mulching. Kumar and Kumar (2010) investigated the effect of Parthenium hysterophorus on seed germination, plumule and radicle length and biomass production of P. mungo. There was a significant reduction with increased concentration of the aqueous solution of Parthenium. Ashok and Pawar (2005) also focused on the effect of Parthenium on different species, and they concluded
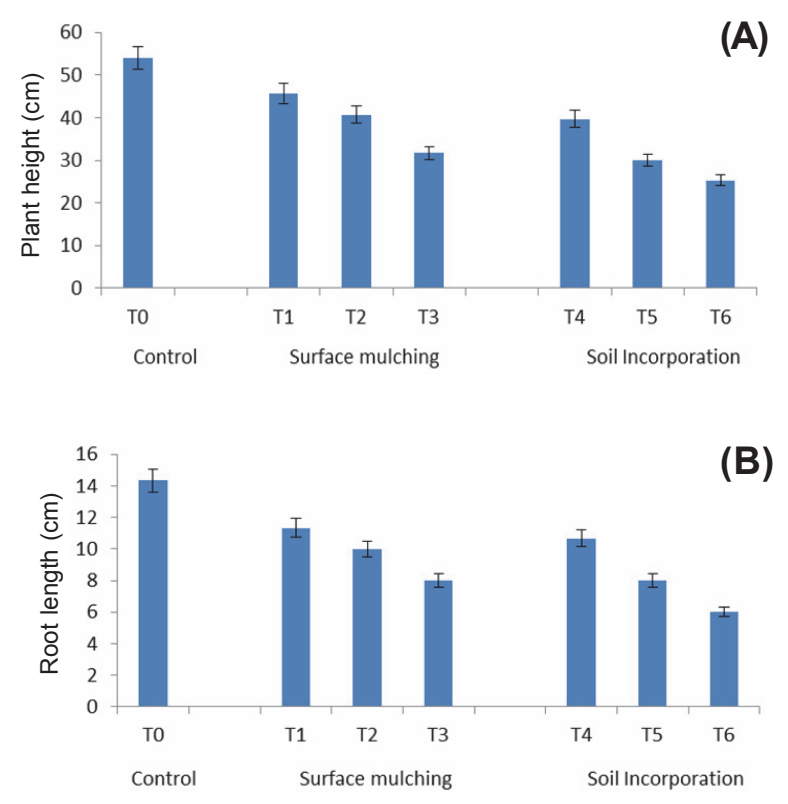

Figure 1 - Influence of Parthenium mulching on (A) plant height and $(B)$ root length of soybean \pm S.E. that all Parthenium extracts significantly reduced root and plumule length. Batish et al. (2002) reported that decomposing residues of Parthenium release water-soluble allelochemicals in bioactive concentrations, which may directly or indirectly affect soil nutrient availability and, thus, plant growth. Parthenium residues released more amounts of phenolics, which accumulate and alter the availability of nutrients in the soil (Facelli and Pickett, 1991; Appel, 1993). Kohli and Batish (1994) confirmed the presence of significantly higher amount of phenolics in the rhizosphere of Parthenium infested areas.

Statistically, maximum leaf area and number of nodules per plant were recorded in the control treatment (Figure 2A, B), where no parthenium was applied. Comparing surface mulching and soil incorporation; soil incorporation had a greater effect on these attributes, in which $\mathrm{T}_{2}$ which showed similar results to those of $T_{4}$, and $T_{3}$, to those of $T_{5}$. These results confirm the finding of Mersie and Singh (1988), who reported that Parthrnium residues reduce plant growth and interfere with nutrient uptake, specifically nitrogen and phosphorus. It has also been reported that Parthenin is a potent inhibitor of germination and plant growth (Batish et al., 2001, 2002).

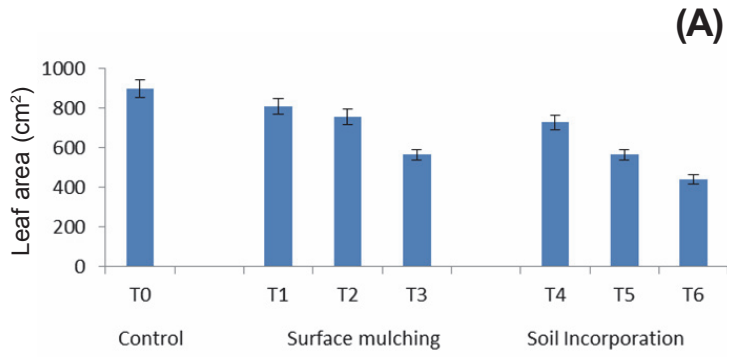

(B)

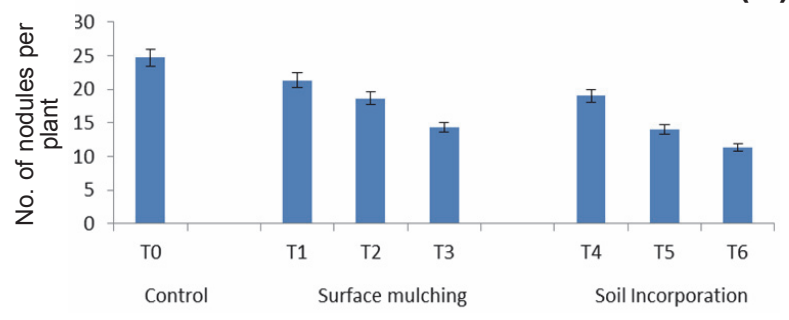

Figure 2 - Influence of Parthenium mulching on the (A) leaf area and (B) number of nodules per plant of soybean \pm S.E.

Planta Daninha, Viçosa-MG, v. 34, n. 4, p. 631-638, 2016 
It has been reported that Parthenium residues release allelochemicals like sequiterpene and phenolics (Daizy et al., 2002; Ramesh et al., 2003), which significantly decreased seed germination and subsequent growth in many crops (PARTHRNIUM WEED..., 2000).

Likewise, the number of pods per plant and the number of seeds per pod were reduced under the Parthenium treatments (Figure 3A,B). Statistically, similar values for number of pods per plant were found in $\mathrm{T}_{2}$ and $\mathrm{T}_{4}$, while $\mathrm{T}_{3}$ and $\mathrm{T}_{5}$ also could not reach the level of significance from each other.Parthenium @ 5 ton ha ${ }^{-1}$ drastically reduced the number of pods per plant in soybean. The number of pods per plant was decreased due to poor growth of the plant (Figure 1A, B). As far as the number of seeds per pod is concerned, $\mathrm{T}_{1}, \mathrm{~T}_{2}$ and $\mathrm{T}_{4}$ showed statistically similar number of seeds per pod whereas a minimum number was recorded in $\mathrm{T}_{6}$ This was also due to effect of Parthenium on plant height and root length, which ultimately affected the growth of soybean plants. The value for 100-seed weight was found to be statistically similar for $\mathrm{T}_{1}, \mathrm{~T}_{2}$ and $\mathrm{T}_{4}$ treatments whereas a minimum value was found for $T_{6}$. and a maximum value was noted in control (Figure 4a). Soybean yield was found to be normal where no Parthenium herbage was used (control) whereas there was continuous decline in yield from $\mathrm{T}_{0}$ to $\mathrm{T}_{3}$, and there was a slight improvement in $\mathrm{T}_{4}$, whereas it started to decline for $\mathrm{T}_{6}$.

The results suggest that a higher concentration of Parthenium retards plant growth, which might be due to inhibition of cell division, as allelopathic chemicals have been found to inhibit gibberellin and indoleacetic acid function (Tomaszewski and Thimann, 1966).

A higher allelopathic potential was shown by the treatments of Parthenium soil incorporation, especially when treatment $\mathrm{T}_{6}$ (soil incorporation of Parthenium herbage @ $5 \mathrm{t} \mathrm{ha}^{1}$ ) was applied. The results suggested that the allelopathic effects of $P$. hysterophorus considerably affected the growth and yield of soybean; therefore, $P$. hysterophorus should be avoided in the agricultural field to increase overall yield of soybean.
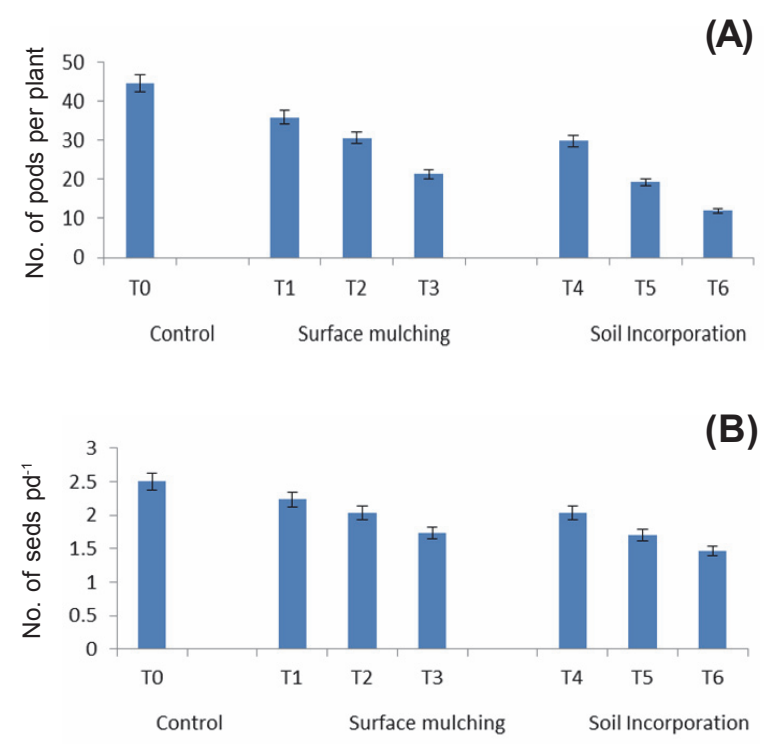

Figure 3 - Influence of Parthenium mulching on the (A) no. of pods per plant and (B) no. of seeds $\operatorname{pod}^{-1}$ of soybean \pm S.E.
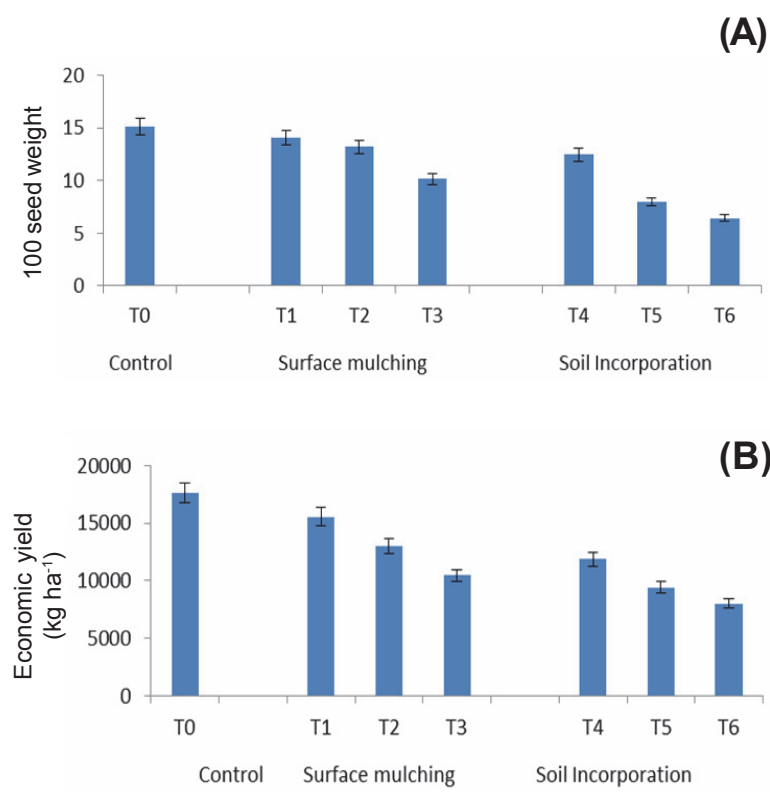

Figure 4 - Influence of Parthenium mulching on the (A) 100 seed weight and (B) economic yield of soybean \pm S.E.

\section{REFERENCES}

Abbasi M.K. et al. Efficiency of rhizobium inoculation and fertilization in enhancing nodulation, seed yield and phosphorus use efficiency by field grown soybean under hilly region of Rawalakot, Azad Jammu and Kashmir, Pakistan. J

Plant Nutr. 2010;33:1080-102. 
Appel H.M. Phenolics in ecological interactions: the importance of oxidation. J Chem Ecol. 1993;19:1521-52.

Ashok S.S., Pawar, K.N. Studies on allelopathic effects of parthenium hysterophrous on some crop species. Agric Sci Digest. 2005;25:166-69.

Balasubramaniyan P., Palaniappan S.P. Field crops. An overview. Principles and practices of agronomy. Pub.byAgrbios (India). 2003;45-6.

Batish D.R. et al. Allelopathic effects of parthenin - a sesquiterpene lactone on germination and early growth of mung bean (Phaseolus aureus Roxb.). PGRSA Quart. 2001;29:81-1.

Batish D.R. et al. Phytotoxic effect of Parthenium residues on the selected soil properties and growth of chickpea and radish. Weed Biol Manage. 2002;2:73-8.

Belz R.G. Allelopathy in crop/weed interactions an update. Pest Manage Sci. 2007;63:308-26.

$\mathrm{Bu}$, Y.S. et al. Effects of different mulch materials on corn seeding growth and soil nutrients contents and distributions. J Soil Water Conserv. 2002;16:40-2.

Channappagoudar B.B. et al. Allelopathic effect of aqueous extracts of weed species on germination and seedling growth of some crops. Karnataka J Agric Sci. 2005; 18:916-20.

Daizy, R.B. et al. Phytotoxic effect of Parthenium residues on the selected soil properties and growth of chickpea and radish. Weed Biol Manage. 2002;2:73-8.

Ellis R.A., Robert, E.H. The quantification of ageing and survival in orthodox seeds. Seed Sci Technol. 1981;9:373409.

Erenstien O. Crop residue mulching in tropical and semitropical countries: An evaluation of residue availability and other technological implications. Soil Till Res. 2002;67:115-33.

Facelli J.M., Pickett S.T.A. Plant litter: its dynamics and effects on plant community structure. Bot Rev. 1991;57:1-32.

Fageria N.K. et al. Growth and mineral nutrition of field crops. 2.ed. New York: Marcel Dekker, 1997. 656p.

Graham P.H., Vance C.P. Legumes importance and constraints to greater utilization to greater utilization. Plant Physiol. 2003;131:872-77.

Javaid A., Anjum T. Control of Parthenium hysterophorus L. by aqueous extracts of allelopathic grasses. Pakistan J Bot. 2006;38:139-45.
Kamara A.Y.P. et al. Selective control of weeds in an arable crop by mulches from some multipurpose trees in Southwestern Nigeria. Agrofor. Syst. 2000;50:17-26.

Khan A.I. et al. Allelopathic effects of parthenium hysterophorus L. on seed germination and growth of soybean, mung bean and maize. Herbologia. 2011;12:129-38.

Kohli R.K.; Batish D.R. Exhibition of allelopathy by Parthenium hysterophorus L. in agroecosystems. Trop Ecol. 1994;35:295-07.

Kruse M. et al. Ecological effects of allelopathic plants. A review. Silkeborg, Denmark: Department of Terrestrial Ecology, 2000. (Rep., 315)

Kumar M.; Kumar S. Effect of Parthenium hysterophorus L. ash on growth and biomass of Phaseolusmungo. Acedemia Arena. 2010;9: 98-102.

Mersie W., Singh M. Effect of phenolic acids and ragweed Parthenium (Parthenium hysterophorus L.) extracts on tomato (Lycoperscion esculentum) Growth and Nutrient and chlorophyll content. Weed Sci. 1988;36:278-81.

Monica V., Rao, P.B. Allelopathic effect of four weed species extracts on germination, growth and protein in different varieties of (Glycine max L.). Merrill. J Environ Biol. 2007;27:571-7.

Khan N. et al. Assessment of allelopathic effects of parthenium (parthenium hysterophorus L.) plant parts on seed germination and seedling growth of wheat (Triticum aestivum L.) cultivars. Pakistan J Weed Sci Res. 2012;18:39-50.

PARTHRNIUM WEED (Parthenium hysterophorus) strategic plan. Launceston: National Weeds Strategy Executive Committee, 2000. 19p.

Picman J., Picman A.K. Autotoxicity in Parthenium hysterophorus L. and its possible role in control of germination. Biochem Syst Ecol. 1984;12:287-92.

Putnam A.R., Baornes J.P. Exploitation of allelopathy for weed control in annual and perennial cropping system. J Chem Ecol. 1983;9:1001-10.

Ramesh C. et al. Pseudoguaianolids from flowers of Parthenium hysterophorus. Photochemistery. 2003;64:8414.

Regina G.B. et al. Residue allelopathy in Parthenium hysterophorus L. Does parthenin play a leading role? Crop Protec. 2007;26: 237-45. 
Sarita K. et al. Impact of Parthenium hysterophorus leaf extracts on the fecundity, fertility and behavioural response of Aedes Egypti. Parasitol Res. 2011;108:853-9.

Singh H.P. et al. Assessment of allelopathic properties of Parthenium hysterophorus residues. Agric Ecosyst Environ. 2003; 95:537-41.

Stamp N. Out of the quagmire of plant defense hypotheses. Quart Rev Biol. 2003;1:23-55.

Steel R.G.D. et al. Principles and procedures of statistics: a biometrical approach. 3.ed. New York: McGraw Hill Book, 1997. 233p.

Stephen W.A., Sowerby M.S. Allelopathic potential of the weed, Parthenium hysterophorus L., in Asutralia. Plant

Protec. 1996;11:20-3.
Tahir M.M. et al. Effect of rhizobium inoculation and NP fertilization on growth, yield and nodulation of soybean (Glycine max L.) in the sub-humid hilly region of Rawalakot Azad Jammu and Kashmir, Pakistan. Afric J Biotechnol. 2009;8:6191-200.

Tefera T. Allelopathic effects of Parthenium hysterophorus extracts on seed germination and seedling growth of Eragrostis tef. J Agron Crop Sci. 2002;188:306-10.

Tomaszewski M., Thimann K.V. Interactions of phenolic acids, metallic ions and chelating agents on auxin induced growth. Plant Physiol. 1966;41:1443-54.

USDA. Office of global analysis, on 2012-13. 18p.

Willis R.J. $<$ http://www.google.com/books?id=CnPBYjDAjYC\&pg=PA3\&>. The history of allelopathy. Springer: 2007;3:8-1. 